\title{
CORPORATE PSYCHOLOGY. HOW DOES ITALIAN ENTREPRENEURSHIP CHANGE?
}

\author{
Adalberto Rangone \\ Department of Economics and Management, University of Pavia, Pavia, Italy \\ adalberto.rangone@eco.unipv.it
}

\begin{abstract}
The analysis on the entrepreneurial system development in the world involves inevitably the question: why in some countries businesses made a specific evolutionary process unlike others? Certainly specific and social conditions as well as economic legacies or regulatory issues promoted by political systems involve. However, these factors are mainly relevant when comparing companies from countries with clear socio-economic disparities. In the presence of a homogeneous economic development, however, other significant factors seem to intervene. Corporate psychology therefore aims to identify the causes conditioning the entrepreneurial choices in developed economies. In Italy, the evolutionary behaviour of enterprises has been clearly conditioned from the entrepreneurs' conception of doing business. This principle involves the choice of the entrepreneurial initiative, the subsequent managerial decisions, and more generally the entrepreneurial fabric development. This paper aims to introduce the topic of the corporate psychology related to new entrepreneurial initiatives in Italy and to propose it as a useful tool for a stable corporate development.
\end{abstract}

Keywords: corporate psychology; entrepreneurship; corporate governance; knowledge capitalism; SMEs.

JEL classification: M13; N00; B30; Z00.

\section{The background of the current entrepreneurial system}

\subsection{The past as possible key to understand the present}

The term entrepreneur indicates one of the most important figures in the process of economic development of the Western world.

As the technologies and the production systems have evolved according to the historical events, so did the entrepreneur. In order to serve this purpose, this figure has always been trying to respond effectively to the needs of its historical period and to meet all the different challenges of the economic system - which is becoming more and more interconnected on an international level.

If we realize the importance of the entrepreneur for the economy, by analysing this figure, we can also make interesting observations about the growth trend of the market and its related components.

In the light of this premise, we intend to analyse the challenges that the entrepreneur has to face at the present day, starting by drawing a brief comparison between the first definition of this figure, theorized by Richard Cantillon (1755), and the current one, influenced by the analysis of all the main economic theorists.

The banker Richard Cantillon, who was born in Ireland, but mainly lived in Paris and London (as a matter of fact he wrote in French), is considered to be the first economist who wrote also about entrepreneurship (Denis, 1973: 180). According to him, the entrepreneur is the person who buys the means of production and uses them to create a product: the product, once sold, allows him to earn a profit. When the entrepreneur invests money, though, is not sure of the outcome. We can therefore say that Cantillon sees the 
entrepreneur as a leader and a risk-breaker; and even if his analysis was quite rudimentary, he was the first economist to put this figure at the center of the cycle of production and distribution. In this way he opened the path to the theories of Walras, Pareto, Marshall and Wicksell and to the neoclassical economic theory in general.

In the neoclassic-marginalist analysis, on the other hand, the entrepreneur is seen as the person who coordinates a corporation and takes risks, while the tout-court capitalist is the person who invests the capital.

We believe that the economist who better understood the entrepreneur on a socioeconomic level might be Max Weber. Weber thinks that the entrepreneur (as we connote him nowadays) is the clear expression of a rationalistic way of thought, and that he differs significantly from the way he was conceived in the previous economic theories, as he pursuits the goal of profits, dedicates himself to economic calculations and subordinates consumption to capital accumulation (Weber, 1974). The Protestant Ethic analysed by Weber (1965) was only one of the causes of the success of Rationalism in the western world and of the consequent rise of the figure of the entrepreneur as we conceive it today. Along with the ethos, other causes were the development of Experimental Science and of the concept of authority (due to the reintroduction of Roman Law and to the Modern State). The author also states that "instrumental rationality", which is a characteristic of the modern entrepreneurial activity, contributed to the creation of new social institutions both public and private (Dodescu, 2011).

It is important to underline, though, that only with Schumpeter we had an accurate and exhaustive analysis of the concept of entrepreneurship. He puts the figure of the entrepreneur at the centre of his theoretical system, thus giving birth to an interdisciplinary branch of studies that involved not only economists, but also historians, sociologists and jurists.

\subsection{The entrepreneurial function as irreplaceable variable of economic development}

For Schumpeter, the function of entrepreneur is the most important variable of economic development (Rangone, 2004: 81). He calls it "innovative activity": the entrepreneur is regarded as an innovator, who finds new combinations of factors of production, new marketing technologies and better ways to satisfy the costumers. These innovations, when credit is granted, can disturb the circular flow and the equilibrium of the economic system. The entrepreneur, who continuously improves the products and creates new production functions, is the prime cause of economic development and generate the process that Schumpeter calls "Creative Destruction". Innovation doesn't require ownership. The fact that, according to the physiocrat and the classic school of thought, the entrepreneur coincides with the capitalist is the result of an analysis that does not consider all the many different aspects of economic life. In addition, Schumpeter argues that the entrepreneur does not necessarily work in a firm, he might be entertaining business with it, or be employed temporarily; on the other hand, the manager has to operate inside the company. It is for this reason that the author does not agree with Marshall's definition of entrepreneurship: it might reduce the importance of the innovative function of the entrepreneur and connote this figure as static. We want to specify here that Schumpeter's idea of the entrepreneur is not only based on economics, but it also has a sociological relevance (Schumpeter, 1972; Schumpeter, 1977).

In order to reform the cultural and social resistances, the entrepreneur has to become a leader. On one hand he has to be similar to political, military and religious leaders of the past. On the other hand the context in which it operates is profoundly different. For these reasons the entrepreneurial action differs from the one explained by the classical economic school with the concept of homo oeconomicus. Schumpeter's entrepreneur is characterized by a combination of rationality and irrationality, and he pursues such objectives that some authors even define prometheic (Badulescu et al, 2011). 
Influenced by Schumpeter, the economist J.K. Galbraith continued the analysis on the crises of the figure of the entrepreneur and of the entrepreneurial class in general. He introduces the concept of "technostructure": an organization in which members can take part to all the decisions (Galbraith, 1968; Galbraith, 1974).

The flows of the analysis, therefore, shift from the entrepreneur (or the entrepreneurial class) to the large corporations (especially those that emerged in USA during the sixties and the seventies of 1900) which have an influence on social values and are influenced by them. In the nature industrial corporations the figure of the entrepreneur does not coincide with a single person, but with a (not precisely defined yet) organ which includes only a part of the people who contribute to the decision-making process.

In the large corporations the power shifts from the entrepreneur to the technostructure, the relationship between a corporation and its technostructure should conform to the one between the technostructure and the individual. The goals of the corporation, the technostructure and the individual should correspond and so should the motivations behind those goals. The goals of the society will tend to be the ones of the joint-stock company and the goals of the joint-stock companies will tend to be the ones of their technostructure's members. In the 1960's the capitalist economic system (especially in the USA) was almost fully controlled by the large corporations; which is a confirmation of what exposed in Galbraith's theories.

In addition to the studies regarding the innovate power of the corporations, another important aspect of such realities was how they were administrated. Corporate governance, which is delegated by the shareholders to exercises power inside a corporation (with direct or indirect consent of the stakeholders) became in those years, matter of research. Those studies investigated on the power of the top management and on the possible conflicts among entrepreneurial class, managers and shareholders (Mella and Velo, 2007).

Moreover it was important to determine who was replacing the entrepreneur in his role after the time of merger and acquisition during the eighties, new social and economic conditions favoured a new rise of the figure of the entrepreneur its creative role had a particular relevance to the small and medium enterprises.

It is in this context (the formation of the new companies even if small or medium sized) that the figure of the entrepreneur regains its centrality as an innovator as Schumpeter theorized the characteristics of the current entrepreneurs is the key role of knowledge capitalism in relation to the decline of the traditional one which was only focused on large corporations (Schumpeter, 1973; Schumpeter, 1977).

The increasing demand for new technologies that generates Schumpeter's creative destruction can modify people's life style, (as for economic reasons they move power structures and even the world itself.

In only a few decades, the world has got such a level of scientific progress that has never been reached before in centuries. If in the past the most valuable capital lay in real estate. Land, raw material and assets, today new technologies, knowledge, and education play a strategic role in the production procedures. In other words, as Peter Drucker, father of the management argued knowledge is and will always be the economic research (Drucker, 1993: 8).

Ad abundantiam we also want to underline here with knowledge capital we indicate the educational background of all the members of a company, which might put the company itself in a more competitive position. The figure of the entrepreneur (a single person or a team) is of course central in the training and updating activity, moreover it coordinates those resources thus creating what we call "the wealth on the third millennium" of the Christian age. 


\section{Analysis of the current entrepreneurial fabric in Italy}

In accordance with the theories of Weber (1965), Marx (1970), Schumpeter (1972) that highlighted the entrepreneur's aim (to seek an innovative idea or a "group" as organizational structure to reach it) we can extend the analysis towards an economicpsychological perspective. In this way we will try to understand the causes that propel the Italian entrepreneur to take a solitary iter oeconomicus.

This process makes it possible to shed light on the psychological motivations that influence economic choices related to the development of the enterprise, and that in the specific case of Italy lead the entrepreneur to develop individual or family enterprises rather than choose shared solutions. In order to introduce this subject we will make an analysis on the current business environment, by identifying the differences that distinguish the Italian firms from others working in countries with a developed economy (Paolone, 2004; Pasinetti, 1984).

\subsection{Empirical data on the entrepreneurial development during the crisis: "Ubi maior minor cessat"}

Compared to the governance structures present in other European countries, we could define the entrepreneurial fabric in Italy extremely limited. The spreading of the enterprises number has undergone considerable evolution slowdowns and showed a significant increase only in the $20^{\text {th }}$ Century (Zattoni, 2015: 242).

The study carried out by A.D. Chandler (1962) concerning the various managerial solutions (U.S., British and German companies) provided a fundamental help, allowing us to understand how the entrepreneurial development in different geographical areas have been conditioned heavily from cultural heritage and stable social framework (Rangone, 2014).

This evolution has led to the development of unique and extraordinary entrepreneurial fabric, thus providing to scholars the chance to analyse companies and classify them for clusters.

In fact, for our purposes, the analysis can be developed according to different criterion of classification:

- by size of enterprise;

- by governance structure;

- by ability to create employment.

On the first point, the available data resulting from the 2011 census are able to express easily with current scenario. A large percentage-equal to $95.2 \%$ of the total - was made up of enterprises with a number of employees between $0-9,3.0 \%$ equal to 134.519 enterprises had a number of employees between 10-19, 1.2\% a number of employees between $20-49$, the $0.5 \%$ consisted of 20.838 enterprises with a number of employees between $50-249$, while only the $0.1 \%$ represented companies with over 250 employees (ISTAT, 2013).The data clearly show that the size of firms in Italy is extremely limited.

In relation with the general entrepreneurial contest made of large pyramidal groups controlled by individual families or by a limited number of shareholders, cooperatives and consortiums, subsidiaries of foreign public companies, the most widespread type of enterprise consist of small and medium-sized family businesses (Zattoni, 2015: 244). The principle to create a business, widely described by Cantillon and pointed out above, is represented by independent small and medium sized family businesses in which the risk for the activity falls entirely on the pater familias or otherwise on the family unit.

We have also to consider this entrepreneurial framework was not facilitated due to international economic conditions severely weakened by the crisis (European Commission, 2011). In addition, the total absence of incentives for small and medium enterprises has facilitated the presence in the Italian market of large international groups that family owned firms cannot face. Therefore, as recited by the Latin motto: "Ubi major minor cessat". 
We want to emphasize, therefore, that this economic trend shows all its cruelty by subtracting fertile soil for the development of small and medium-sized enterprises which, as noted earlier, are the base of the Italian economy. This process, however, has limited but not prevented continuous turnover in place for nearly a decade (CERVED, 2015) whereby new enterprises are to replace those no longer able to sustain the pace of an economy in crisis. Data on new initiatives in 2014 can be summarized in the following table:

Table 1: New business initiatives at 2014 (percentage values compared with 2013)

\begin{tabular}{|c|c|c|}
\hline Individual enterprises & Società di persone & Società di capitali \\
\hline 168,000 & 25,000 & 83,000 \\
\hline$-2.2 \%$ & $-4.9 \%$ & $+15.8 \%$ \\
\hline
\end{tabular}

Source: CERVED, 2015

As you can see in the table above the best values were recorded by "società di capitali" with an increase higher than 15\% in comparison with the births of 2013; while in the case of sole proprietorships and "società di persone", was a slight decrease but does not indicate a worrying trend.

In order to provide one possible interpretation because the number of start-ups is increased in the form of società di capitali compared to sole proprietorship or società di persone, we would like to say that in Italy società di capitali is the best form to protect the business partners against the risks for the activity carried out (Guatri, 2000); and this is not to be neglected in times of crisis.

Table 2: Growth rate of new business initiatives, by geographical data

\begin{tabular}{|c|c|c|c|}
\hline North West & North East & Centre & South \\
\hline$+2.9 \%$ & $+0.9 \%$ & $+1.8 \%$ & $+2.8 \%$ \\
\hline
\end{tabular}

Source: CERVED, 2015

At the same time, we consider interesting the surveys related to the entrepreneurial development of new business initiatives by region. Higher growth rates were seen in the North West of the country and in the South.

In the general context of start ups' birth, we also have to note the ever increasing adaptation to international trends of enterprise development.

The IT and scientific research fields are increasingly shared by new generations of entrepreneurs. In 2014 (CERVED, 2015) start-ups registered in these areas were 1.256, scoring so an increase equal to $+36 \%$ compared with 2013 and establishing a network of approximately 3.000 companies.

\subsection{The performance of High Growth firms and Gazelle firms in Italian business environment}

The appearance of the terms "High Growth" and "Gazelle" on the economic scenario of Italian firms is relatively new. Indeed their importance has increased when in times of crisis have been investigated business structures more inclined to create employment net gross or generated (Nightingale and Coad, 2014; Daunfeldt et al, 2013; Bertini et al, 2015).

These two types of businesses have been inserted into a heterogeneous landscape of business forms and have acquired enough importance due to their dynamic capabilities and occupational development.

As we discussed in the first part of this chapter, the types of Italian firms are related substantially to the principle of family business.

However, observing them under the criterion of annual growth and ability to quickly adapt to the evolutionary trends, we can clear identify their increasing importance in relation to the entrepreneurial system. 
In the context of small businesses, in fact, High growth and Gazelle firms demonstrate higher dynamic capabilities and greater financial resources. (Bertini et al, 2015)

Often these two corporate forms are confused with each other, and the two terms become almost synonyms; let's see then what the substantive features are and how their development appeared in Italy during the period 2012-2014. The High-Growth businesses are those firms with at least 10 employees at the beginning of the year that have an average annual growth in terms of employees exceeding $20 \%$ for three consecutive years (OECD, 2012) while the term Gazelle identifies companies operating from 4 / 5 years.

We must remember that values attested by companies High Growth, identified with the following formula:

$$
\sqrt[3]{\frac{\text { employees }_{t}}{\text { employees }_{(t-3)}}-1}
$$

which in this case must express values $>0.2$ to $t-3$, are very important as they represent measures of business performance relating to the ability to create jobs.

Table 3: Evolution of High Growth and Gazelle firms in Italy in the period 2012-2014

\begin{tabular}{|c|c|c|c|c|}
\hline Years & $\begin{array}{c}\text { H.G. } \\
\text { growth rate }\end{array}$ & H.G. firms & Gazelle growth rate & Gazelle firms \\
\hline \multicolumn{5}{|c|}{ INDUSTRY } \\
\hline 2012 & $1.6 \%$ & 984 & $0.2 \%$ & 108 \\
\hline 2013 & $1.7 \%$ & 1.043 & $0.2 \%$ & 122 \\
\hline 2014 & $1.7 \%$ & 995 & $0.2 \%$ & 107 \\
\hline \multicolumn{5}{|c|}{ CONSTRUCTIONS } \\
\hline 2012 & $1.8 \%$ & 385 & $0.3 \%$ & 65 \\
\hline 2013 & $1.9 \%$ & 371 & $0.3 \%$ & 55 \\
\hline 2014 & $2.1 \%$ & 364 & $0.3 \%$ & 57 \\
\hline \multicolumn{5}{|c|}{ TRADE } \\
\hline 2012 & $2.3 \%$ & 668 & $0.3 \%$ & 83 \\
\hline 2013 & $2.3 \%$ & 665 & $0.3 \%$ & 76 \\
\hline 2014 & $2.4 \%$ & 652 & $0.3 \%$ & 66 \\
\hline \multicolumn{5}{|c|}{ OTHER SERVICES } \\
\hline 2012 & $4.0 \%$ & 1.678 & $0.7 \%$ & 295 \\
\hline 2013 & $4.2 \%$ & 1.768 & $0.7 \%$ & 300 \\
\hline 2014 & $4.5 \%$ & 1.818 & $0.8 \%$ & 304 \\
\hline \multicolumn{5}{|c|}{ TOTAL } \\
\hline 2012 & $2.4 \%$ & 3.715 & $0.4 \%$ & 551 \\
\hline 2013 & $2.5 \%$ & 3.847 & $0.4 \%$ & 553 \\
\hline 2014 & $2.7 \%$ & 3.829 & $0.4 \%$ & 534 \\
\hline
\end{tabular}

Source: Istituto Nazionale di Statistica (ISTAT), 2015

Observing Table 3, you can see the growth of High-Growth (H.G.) enterprises rate and Gazelle, which in 2014 amounted respectively around to $2.7 \%$ and at $0.4 \%$.

With reference to these two types of businesses we can also emphasize how employment growth has affected manufacturing, construction and mining companies ( $8.7 \%$ for H.G. and $1.3 \%$ for Gazelle) in comparison with the huge leak detected by the common enterprises (90.0\%) (ISTAT, 2015). 


\section{Start-up and performance. Solutions for the development}

In the previous paragraph we have analysed the growing importance of Gazelle and H.G. Businesses. The role they have for the maintenance of the Italian entrepreneurial economy is crucial.

These two innovative entrepreneurial forms express precisely the need to survive in adverse economic conditions, such as lack of adequate reforms for the development or the reduction of bank credit access (Rangone, 2011; Rangone, 2004).

They are the clearest manifestation that Italian entrepreneurial sector - always tied to small and medium firms - has researched the best strategic solutions for recruiting qualified personnel, for the valuating the corporate performance or the know-how enhancement (Rangone, 2012) in order to make up for the lack of suitable economic conditions for development.

Nowadays it's difficult to establish a business. People who want to start an enterprise have to face this reality every day. On an international level all of the enterprises are dealing with the same problems: the decrease in demand, the late payment terms and an increasing difficulty in taking out a loan. The global market is becoming more and more competitive (Sargiacomo, 2000) and the new challenges more difficult to meet. For these reasons the SMEs are declining especially if compared with the large enterprises (Preti, 2011).

Moreover starting-up enterprises have to deal with three kinds of capital: human capital, financial capital and entrepreneurial capital (Mattoscio and Colantonio, 2011).

Human capital needs education or at least a technical training in order to make an enterprise competitive.

In economic system in which High-Tech is essential and the market is innovation-oriented, it is important for the enterprises to provide internal training and to increase access to hire education.

We can therefore say that qualification is the key to best employee human capital.

Financial capital has always been the biggest problem for an enterprise in the start-up phase (Zamagni, 2011).

Nowadays in Europe it is difficult to start a new business using seed capital or venture capital, whereas this is very frequent in USA (European Parliament, 2012).

In addition to these hostile conditions, the burden of taxation has risen considerably and this fact has deeply affected the choices, both old and new. The difficult economic growth brought the entrepreneurs to look for new alternatives on an international market. An example-enterprise might be led by Italian entrepreneurs, be financed with U.K founds and employ Chinese man power. The global system has surely opened new possibilities on the economic scenery; the entrepreneurs have been challenged to adapt themselves to the new economy: but on the on the other hand not much has changed since the times when people with warship and cannons-today we should say high-technology and global financeopened the way for European capitalism to succeed (Cipolla, 1999). The entrepreneur - in this context considered a part of the capital - needs to go beyond its limits by exploring new economic worlds. Only by knowledge and technical ability the new SMEs can survive and evolve in a global contest.

This is most diffused theory, but it is not the only one (Kaldor, 1965; Solow, 1973; Solow, 1968). The example of fast-growing companies shows that a better management of human capital and the entrepreneurial aggregation could prevent a sort of diaspora towards other countries with better economic conditions.

For this reason we would like to conclude the present work with this statement: if an efficient human capital management involves business opportunities for development and for employment in times of crisis, why do Italian firms continue to follow a solitary way, just to maintain the corporate control? 


\section{In conclusion}

By this work we've intended to make a sort of excursus from the primordial business concepts to the current development of the entrepreneurial fabric, in order to better understand which were the substantial changes in the way of doing business in Italy.

The reference to historic-economic concepts seemed important in order to show that Italian entrepreneurial fabric is still anchored to the figure of the entrepreneur and differs widely by the complex managerial structures present in the United States, in Germany or in other more developed countries. The challenges that the pater familias has to face are numerous and no more limited to simple and constant research for the product innovation, as well as anticipated by Cantillon or Schumpeter.

Today, the company - personally or family managed - has to face challenges with purely managerial connotations. These require a change in the concept of enterprise and how it develops. The international crisis has prompted Italian companies before a crossroads: evolution or extinction. The development of Gazelle or H.G. firms is the sign that small and medium-sized Italian companies should trust more in human resources and in the value they may lead to the product offered.

If Cantillon in $18^{\text {th }}$ century outlined the entrepreneur as one who risks every day trying to allocate his product on the market, today this figure seems to have not changed greatly from the original one. However, otherwise occurs in other developed countries.

In our humble opinion, the Italian small and medium enterprises can follow the path of evolution only through greater use of human capital and the willingness to share managerial solutions.

The study of corporate psychology can then act as a valuable tool to help entrepreneur during the process of renewal.

\section{References}

Badulescu A. and Badulescu D. (2011). L'imprenditore e la sua funzione prometeica, in Rangone E.C. (ed.), Lo Spirito dell'Economia. La direzione di una grande orchestra, Pavia: Pavia University Press.

Bertini S., Ferraresi T., Mariani M. and Rossi L. E. (2015). High-growth firms, the role of management and capabilities, IRPET Editore, Firenze.

Cantillon R. (2001). Essay on the Nature of Commerce in General, Transaction Publishers, first published 1755, Piscataway, New Jersey.

CERVED (2015). Osservatorio nuove imprese e startup 2014, available at: www.cerved.com, [26 02 2016].

Chandler A. D. (1962). Strategy and Structure: Chapters in the History of the American Industrial Enterprise, Beard Books.

Cipolla C.M. (1999). Vele e Cannoni, Bologna: Edizioni II Mulino.

Daunfeldt S.O., Coad A., Holzl W., Johansson D. and Nightingale P. (2013). High-growth firms: introduction to the special section, Oxford: Oxford University Press.

Denis H. (1973). Storia del pensiero economico, trad. it., Milano: Mondadori.

Dodescu A.O. (2011). Per un definitivo superamento del dualismo Stato - Mercato, in Rangone E.C. (ed.), Lo Spirito dell'Economia. La direzione di una grande orchestra, Pavia: Pavia University Press.

Drucker P.F. (1993). Postcapitalist Society. New York: HarperCollins Publishers.

European Commission (2011). Are European SMEs recovering from the crisis? Annual Report on EU small and medium-sized enterprises 2010/2011"Rotterdam, Cambridge.

European Parliament (2012). Potential Of Venture Capital in the European Union, Directorate-General for Internal Policies Report.

Galbraith J.K. (1968). II nuovo stato industriale, Edizioni Einaudi, Torino.

Galbraith J.K. (1974). L'economia e l'interesse pubblico, Milano: Arnoldo Mondadori Editore. 
Guatri L. (2000). Trattato sulla valutazione delle aziende, Milano: EGEA Edizioni, Università Bocconi.

Istituto Nazionale di Statistica (ISTAT) (2013). $9^{\circ}$ Censimento generale dell'industria e dei servizi e Censimento delle istituzioni non profit, available at: http://censimentoindustriaeservizi.istat.it/, [03 03 2016].

Istituto Nazionale di Statistica (ISTAT) (2015). L'imprenditorialità in Italia, statistical focus, available at: www.istat.it, [03 03 2016]..

Kaldor N. (1965). Un modello dello sviluppo economico, in Saggi sulla stabilità economica e lo sviluppo, trad. it., Torino: Einaudi.

Marx K. (1970). Il capitale, trad. it., Milano: Newton Compton.

Mattoscio N. and Colantonio E. (2011). Economia e sviluppo Umano, in Rangone E.C. (ed.), Lo Spirito dell'Economia. La direzione di una grande orchestra, Pavia: Pavia University Press.

Mella P. and Velo D. (2007). Creazione di valore, Corporate Governance e informativa societaria, Milano: Giuffrè Editore.

Nightingale P. and Coad A. (2014). Muppets and gazelles: political and methological biases in entrepreneurship reasearch, Oxford: Oxford University Press.

OECD (2012). Entrepreneurship at a Glance, available at www.oecd.org, [28 02 2016].

Paolone G. (2004). Assetti di Governance e modelli societari, Torini: Giappichelli.

Pasinetti L. (1984). Dinamica strutturale e sviluppo economico - un'indagine teorica sui mutamenti nella ricchezza delle nazioni, Torino: UTET.

Preti I. (2011). Il meglio del piccolo - I'Italia delle PMI: un modello originale di sviluppo per il Paese, Milano: Edizioni EGEA, Università Bocconi.

Rangone A. (2014). 'Market, Cultural Heritage and the Solution to the Corporate

Governance Problems', Annals of the University of Oradea: Economic Sciences, Tom XXII, no. 1 (July), pp.390-402.

Rangone A. (2012). Emerging Challenges for Entrepreneurship and SMEs in the context of Knowledge Capitalism and Glocalization, in Proceedings of the European Conference on Innovation \& Entrepreneurship, Santarem September 2012, Vol. 2, pp. 853- 861.

Rangone E.C. (2011). Lo spirito dell'economia. La direzione di una grande orchestra, Pavia: Pavia University Press.

Rangone E.C. (2004). Elementi di economia e politica dello sviluppo, Oradea: University of Oradea Press.

Sargiacomo M. (2000). II BenchMarking nell'azienda comune. Profilo economicoaziendale, approccio metodologico, sistema di rating delle condizioni di successo, Torino:Giappichelli.

Schumpeter J.A. (1973). Capitalismo.Socialismo.Democrazia, trad. it., Milano: Etas Kompass.

Schumpeter J.A. (1972). Storia dell'analisi economica, trad it., Torino: Boringhieri.

Schumpeter J.A. (1972). Teoria economica e storia imprenditoriale", trad. it., in Cavalli A., Economia e società, Bologna: II Mulino.

Schumpeter J.A. (1977). Teoria dello sviluppo economico, trad. it, Firenze: Sansoni editore. Solow R.M. (1968). II cambiamento tecnico e la funzione aggregata di produzione, in Jossa B. (ed.) Progresso tecnico e sviluppo economico, Milano:Franco Angeli.

Solow R.M. (1973). La teoria della crescita", trad. it., Milano: ISEDI.

Weber M. (1965). L'etica protestante e lo spirito del capitalismo, trad. it., Firenze: Sansoni editore.

Weber M. (1974). Economia e società, trad. it., Milano: Edizioni di Comunità,.

Zamagni S. (2011). Cooperazione di credito e sviluppo civile: come esaltare il potenziale identitario delle $B C C$, Working Papers 81 , Università di Bologna.

Zattoni A. (2015). Corporate governance, Milano: Egea. 


\section{Bio-note}

Adalberto Rangone has a degree and a Ph.D. in Economics at University of Oradea and University of Pavia (joint supervision). Currently, he is Research Fellow at the University of Pavia (Italy), Department of Economics and Management. His main interests refer to Corporate Governance and Governance of the Foundations of Banking Origin. In the meanwhile, Adalberto Rangone is Mediator in Business Controversy and Business Consultant, assisting customers in many worldwide countries as: Romania, Morocco, Algeria and Ukraine. 